\title{
Unicórnias pretas contra a necropolítica: tensões em Além do princípio do prazer
}

\author{
Black Unicorns Against Necropolitics: \\ Tensions in Beyond the Pleasure Principle
}

\author{
Alessandra Affortunati Martins Parente \\ Doutora em psicologia social pela USP/ Pós-doutoran- \\ da em filosofia pela USP/ FAPESP
}

Resumo: O artigo se propõe a desenvolver quatro tarefas: 1) apresentar reflexões acerca do erotismo, considerando-o como recurso de luta disponível para as mulheres; 2) contrapor o erotismo e a intensidade afetiva à melancolia, considerada como espírito da modernidade; 3) Superar a dicotomia Eros e Thanatos que marca a noção freudiana de conflito pulsional em Além do princípio do prazer, sem com isso propor alternativas monistas. Diversamente, a ideia é mostrar o caráter histórico entranhado na vertente conflitiva pulsional, vista por Freud pelo viés puramente econômico do aparelho psíquico; 4) Levando em conta a história, aparecem duas formas distintas de conceber a temporalidade da existência humana e seus modos de ordenação simbólico-culturais e políticas: a transitoriedade e a fixação melancólica. Nenhuma dessas duas formas de conceber a história e a temporalidade, ligadas aos conflitos econômicos do psiquismo, servirá aqui - a elas oferecerei uma terceira saída, fundada em dois pilares: firmeza e valor.

Palavras-chave: Melancolia, Erotismo, Pulsões, Necropolítica. 
Abstract: The article proposes to develop four tasks: 1) to present reflections about eroticism, considering it as a fighting resource available to women; 2) counteract eroticism and affective intensity to melancholy, considered as the spirit of modernity; 3) Overcoming the Eros and Thanatos dichotomy that marks Freud's notion of drive conflict in Beyond the Pleasure Principle, without thereby proposing monistic alternatives. On the other hand, the idea is to show the historical character embedded in the conflictive drive, viewed by Freud from the purely economic bias of the psychic apparatus; 4) Taking into account history, two distinct ways of conceiving the temporality of human existence and their modes of symbolic-cultural and political ordering appear: transience and melancholy fixation. Neither of these two ways of conceiving history and temporality, linked to the economic conflicts of the psyche, will serve here - I will offer them a third way, founded on two pillars: firmness and value.

Keywords: Melancholy, Eroticism, Drives, Necropolitics.

$\mathbf{O}^{\prime}$ feminismo é feito de numerosas e densas camadas, todas elas articuladas de maneira tensa e vibrante. Quase não há consenso nessa seara. Essa pequena contribuição situa-se, portanto, em um território no qual o chão nunca é firme o suficiente para que estejamos seguras. Há sempre riscos de que algum pedaço do solo trinque, tornando instável toda a base de uma luta comum das mulheres contra o poder patriarcal. De qualquer maneira, a instabilidade não deve ser óbice e tais riscos precisam ser assumidos - não deve haver recuo quando adentramos o debate feminista, já que as mulheres estão, todas elas, em formação, isto é, ensaiando possibilidades diversas de organizações político-sociais e de forças reflexivo-intelectuais capazes de sustentar alternativas viáveis à ordem falida que se estabeleceu pelo patriarcado.

Tomando a incumbência de seguir adiante com essa arriscada tarefa, limito-me a quatro objetivos neste trabalho: 1) apresentar de maneira ainda bastante errante minhas mais recentes reflexões acerca do erotismo, considerando-o como recurso de luta disponível para as mulheres; 2) contrapor o 
erotismo e a intensidade afetiva à melancolia, considerando-a não stricto sensu, isto é, de uma perspectiva subjetiva, mas sobretudo lato sensu: uma forma espiritual própria à era moderna, tal como já demonstrara Walter Benjamin (1928/2011) a partir dos dramas do Barroco alemão; 3) Superar a dicotomia Eros (pulsão de vida e erotismo) e Thanatos (pulsão de morte e melancolia) que marca a noção freudiana de conflito pulsional em Além do princípio do prazer, sem propor, como se costuma fazer, uma espécie de monismo alternativo, que recai num dos dois polos em tensão. Procurarei, diferentemente, introduzir o caráter histórico entranhado nessa vertente conflitiva pulsional, puramente econômica do aparelho psíquico; 4) Com esse viés histórico, serão desenhadas duas formas distintas de conceber a temporalidade da existência humana e seus modos de ordenação simbólico-culturais e políticas: a transitoriedade e a fixação melancólica. Nenhuma dessas duas formas de conceber a história e a temporalidade, atreladas aos conflitos econômicos do psiquismo, servirá aqui - a elas oferecerei uma terceira saída, fundada em dois pilares: firmeza e valor.

Além desses quatro fins propostos, há outro componente para o qual o leitor deve ser alertado nesta breve introdução: o caráter formal deste ensaio não será bem-acabado. Nele será possível identificar os processos intelectuais e identificatórios envolvidos em sua tessitura e os fios soltos de reflexões que permitiram sua construção. Em suma, aquilo que geralmente se mantém nos bastidores do processo de escrita, ou que se apaga após sua finalização, assumirá aqui um outro lugar. Essas rebarbas farão parte do corpo do texto por motivos éticos, estéticos e em razão de um compromisso com a verdade, ligada ao que efetivamente alimenta e move a realização de um trabalho político e intelectual - mais do que reflexões polidas e abstratas, são diferentes afetos de tonalidades eróticas que o movem de maneira vivaz e eles terão espaço aqui.

\section{Melancolia fora de tempo, fora de lugar}

À semelhança da melancolia, deslocada temporal e espacialmente, há uma frase que, em meio a tantas outras conca- 
tenadas em Sublimação e Unheimliche (Parente, 2017), não se acomoda facilmente às minhas elucubrações e articulações teóricas ali expostas. Emerge em minhas lembranças como fenômeno unheimlich - embora a estranhe, ela insiste em se afirmar como verdade, evidentemente não-toda. Independentemente do desconforto que ela provoca em meus pensamentos, decidi mantê-la como parte daquele livro. Seu desajuste faz com que ela reverbere e estremeça construções teóricas ali tecidas. Sempre que relida, abala minhas certezas. Depois, cala-se em meio ao todo. É na página oitenta e cinco que se lê: "Na esfera atual [...], o melancólico - ou o depressivo - seria um ser anacrônico". É uma frase prenhe de consequências, ainda mais quando proferida por uma psicanalista.

Julia Kristeva (1998), por exemplo, atribui à melancolia uma dimensão quase ontológica, ao afirmar: "sem uma disposição para a melancolia, não há psiquismo, mas atuação ou jogo". (p. 12). Ora, diante dessa contundente afirmação da filósofa-psicanalista, a frase recobrada de meu livro emerge de maneira vertiginosamente perigosa, colocando-me como uma psicanalista que recusaria as próprias condições de possibilidade para a existência do psiquismo. Ou ainda mais radicalmente: seria possível me manter no lugar de psicanalista ao supor o anacronismo da melancolia? Basta pensar no traço melancólico que sustenta a própria Lei pelo Nome-do-Pai para perceber que tenho um problema e tanto a ser enfrentado - culpa pela morte do pai, nostalgia de seu poder e proteção, memória perpétua de seu invejável lugar. Vejamos, então, como posso sair de tal enrosco.

Não seria prudente, em nome de uma hipótese um pouco excêntrica, tapar os olhos para casos de depressão e melancolia na clínica contemporânea. Sim, pois é claro que a depressão se apresenta a todo vapor diante de nossos olhos. Evidente que se trata de uma epidemia atual, sobre a qual se dedicam estudos nos mais variados campos, sendo o fenômeno do suicídio, cada vez mais frequente, uma de suas possíveis e preocupantes consequências. Não só: a melancolia poderia ser alocada num plano universal e, assim invocada, se tornaria um meio forte de contestar a instável frase que insisti em reter. 
Tema recorrente desde a Antiguidade Clássica até a Idade Média, a melancolia passou pelo Renascimento, atravessou os dramas do Barroco, chegou à modernidade com tons românticos e se instalou na contemporaneidade com toda sua intensidade mórbida, distante dos anseios mercadológicos de alta produtividade no campo do trabalho. A melancolia se impõe e dela não se pode escapar... ainda!

O que tinha em mente ao escrever aquelas poucas palavras articuladas numa frase sucinta, era a ideia de que o Zeitgeist melancólico da modernidade implicava um intenso investimento libidinal em figuras que, embora já claramente mortas, de um modo ou de outro, ocupavam espaços fantasmáticos de autoridade e exerciam poder opressor sobre o sujeito acometido pelo estado de espírito taciturno.

Isso talvez fique mais claro numa subdivisão estabelecida por Michel Foucault (apud Santiago, 2015) a partir da filosofia nietzschiana. De acordo com Lívia Santiago, o filósofo francês diferencia três espécies de niilismo: o negativo, o passivo e o ativo. Nas palavras da autora:

O primeiro estaria ligado à religião e à noção de que a vida perfeita está no outro mundo - o que faz com que o sujeito não aja de acordo com as contingências que a vida exige. O segundo é aquele que não consegue encontrar sentido na vida, uma vez que ela chegará ao fim. Finalmente, no niilismo ativo, ultrapassa-se a simples constatação de que a vida não tem sentido nenhum. Aqui a ideia seria viver intensamente o hoje e não negar o mundo, o niilismo ativo é a antítese da covardia diante da vida, ele seria a condição de possibilidade para se criar novos valores. (Santiago, 2015)

Quando se olha atentamente para a classificação do niilismo, feita por Foucault, percebe-se, na primeira subdivisão, uma existência desvitalizada, sustentada por outra imaginária e perfeita ao lado de Deus ou de alguma espécie de Paraíso imaculável - o eterno sonho cristão com uma outra vida, longe dos pecados da carne. No segundo caso, há mais visivelmente alguns efeitos da acedia, isto é, o sujeito recua de modo obsessivo e não penetra os meandros daquilo que se apresenta, preservando intacto tanto objetos de seu desejo como seu próprio eu. O paradigma desse modelo é o príncipe dos dramas do Bar- 
roco alemão e suas dúvidas obsessivas sobre a legitimidade de seu posto soberano. A vida considerada sem sentido é uma vida que ainda anseia por sentidos que emerjam de fora, sentidos que sejam dados por alguém que os detém e que estejam prontos em algum lugar misterioso. O niilismo ativo, por sua vez, apresenta uma conexão com o caráter circunstancial da vida, já que a negatividade está desvencilhada de qualquer expectativa ou temor - embrenhar-se na contingência para dela extrair matéria e engendrar novos contornos possíveis de existência e de formas simbólicas. Daí ser possível constatar como os dois tipos de niilismo diferenciam-se do último - naqueles uma sombra de autoridade ainda está suposta em algum lugar, ao passo que na última forma não resta nada a não ser a própria vitalidade das circunstâncias e o que ela é capaz de convocar do passado e projetar para o futuro.

Em 1917, Freud (2010) explicou o mecanismo psíquico da melancolia, diferenciando-o do processo de luto. Enquanto a este refere-se à dor e ao sofrimento da perda, parte da existência de todos nós, a melancolia traz o sofrimento como solução de compromisso narcísica e sadomasoquista. O sujeito melancólico é aquele que mumifica o objeto perdido no interior do mausoléu egóico, elevando-o e preservando-o como ideal, no mesmo passo em que o eu é atacado, depreciado e sufocado pelo peso do objeto fantasmagórico. O fundamento desse estratagema sintomático é a culpa em relação a tal figura perdida - o ódio, parte do amor sempre ambivalente, não pode ser admitido pelo sujeito melancólico, que, então, mantém-se imerso em sua eterna dívida ante o objeto idealizado. Por outro lado, a experiência clínica também ensina sobre a impossibilidade de elaborar o luto em função da primazia do ódio em relação ao objeto perdido. Falta, diria Melanie Klein (1957/1991), a gratidão, que só se apresenta quando o amor pode ser reconhecido em sua necessária parcialidade e imperfeição. Seguindo as linhas da psicanálise clássica, Kristeva assim define a depressão:

Segundo a teoria psicanalítica clássica (Abraham, Freud, M. Klein) a depressão, assim como o luto, esconde sua agressividade contra o objeto de seu luto. "Eu o amo (parece dizer o depressivo a propósito de um ser ou de um objeto perdido), mas o odeio ainda mais; 
porque o amo, para não perdê-lo, eu o instalo em mim: mas porque o odeio, esse outro em mim é um mau eu, sou mau, sou nulo, me mato.". A queixa contra si seria portanto uma queixa contra um outro e a autocondenação à morte, um disfarce trágico do massacre de um outro. Concebemos que tal lógica supõe um superego severo e toda uma dialética complexa da idealização e da desvalorização de si e do outro, repousando o conjunto desses movimentos no mecanismo da identificação. Pois é identificando-me com o outro amado-odiado, por incorporação-introjeção-projeção, que instalo em mim sua parte sublime, que se torna meu juiz tirânico e necessário, assim como sua parte abjeta, que me rebaixa e que desejo liquidar. A análise da depressão passa, por consequência, pela evidenciação do fato de que a queixa de si é um ódio contra o outro e que este, sem dúvida, é a onda portadora de um desejo sexual insuspeito. (Kristeva, 1998, pp. 17-8)

De acordo com Kristeva, o sublime indicaria a Coisa, gozo inconcebível e inapreensível ao melancólico que rumina seus dramas. A Coisa é o objeto de desejo purificado de seu revestimento erótico. Como alguém deserdado de um bem supremo intangível, o melancólico devoto aposta que sua fidelidade ao Outro e atos de fé a ele dedicados lhe farão digno da Coisa, sempre perdida e sempre invocada. Com laços expurgados das máculas do desejo, a Coisa escraviza a libido e impede que objetos eróticos ocupem seu lugar. Nas palavras de Kristeva: "sabendo-se deserdado de sua Coisa, o depressivo foge, perseguindo aventuras e amores sempre decepcionantes, ou então se fecha, inconsolável e afásico, num tête à tête com a Coisa não nomeada"1. (Kristeva, 1998, p. 20)

Kristeva estabelece uma antítese entre Coisa erótica e Coisa melancólica para indicar que, na melancolia, a identificação primária não está suficientemente garantida e outras identificações simbólicas de teor erótico ficam comprometidas. A Coisa erótica converte-se em objeto de desejo cativante quando é capaz de se estender sob forma de uma metonímia do prazer. De outro lado, a Coisa melancólica interrompe ou impede a

$1 \quad$ Fica claro como Julia Kristeva (1998) não usa aqui a noção de Coisa [das Ding] no mesmo sentido dado por Jacques Lacan. Separando a Coisa do objeto erótico, Kristeva concede consistência material de teor sexual a este e expurga a Coisa de qualquer erotismo. Isso fica mais claro com outra distinção mais precisa, feita pela autora, entre Coisa erótica e Coisa melancólica, como ficará claro subsequentemente. 
metonímia desejante. Nesse contexto desenhado por Kristeva, a sublimação emerge como saída possível da Coisa melancólica. Em suas palavras, a sublimação "é o único 'continente' que parece assegurar um domínio incerto, mas adequado, sobre a Coisa" (Kristeva, 1998, p. 20). Talvez, porém, possamos questionar se ainda convém insistir em formas simbólicas que se apresentem como consolos ante a Coisa erótica, como continentes que possam atenuar sua força, como saídas menos intensas sobre seus impactos ou como domínios sobre o poder próprio a ela - tarefa que só será feita mais adiante.

Ao ter que se desvencilhar do erotismo inerente aos afetos que conectam sua libido ao objeto, o melancólico deixa de abarcar a complexidade daquilo que se apresenta como causa de seu desejo. Na falta de complexidade dos afetos, resta o artifício da cisão defensiva. Ou o objeto é idealizado e amado como totem indestrutível ou odiado e trucidado já que, apesar de imaginariamente provido de todo o poder, é visto como aquele que negligencia as necessidades e desejos inconfessáveis do sujeito, sempre insatisfeito. Alvo de revolta e inveja, o objeto promove ressentimentos e a adesão imperscrutável da libido às suas piores características.

Nota-se, por conseguinte, que o melancólico atribui poder insuperável ao objeto enaltecido por um amor unívoco ou depreciado por um ódio sem ambivalências. Eternamente idolatrado em sua versão mumificada, tal relação objetal impõe uma dívida eterna e impagável. Abandonar o objeto significará traí-lo em nome de um desejo singular, passo inadmissível para o melancólico. Para ele, o desejo não pode jamais enunciar-se sob pena de indicar a fissura entre o sujeito, que se faz objeto do Outro, e este que aparece imaginariamente preenchido pela mortífera e inquestionável devoção. Quando odiado, a articulação psíquica é a mesma, só que em sentido inverso: depositário de ódio desmedido, o Outro supostamente poderia ter feito muito mais, poderia ter suprido todos os anseios do sujeito, evitado todos os seus sofrimentos e suas dores, tapado todos os buracos de sua carne e de seu espírito. 
Retomando aqui a ideia anteriormente apresentada de que a melancolia seria um estado de espírito anacrônico, referia-me ali a um evento inédito e de grande magnitude que poderia desmoronar, de uma vez por todas, alguns dos sustentáculos através dos quais mantínhamos intactas certas estruturas sociais e políticas modernas do Ocidente: a Primeira Guerra Mundial. Depois dela, não há razão que justifique a insistência em crer na legitimidade daqueles que ocupam lugares de poder na estrutura moderna da soberania. Não há motivo para devoções, ideais ou expectativas de alta monta em figuras patriarcais de autoridade, estejam elas nas pequenas estruturas familiares, estejam elas nas superestruturas. Em suma: o anacronismo da melancolia se deve ao fato de que, por diferentes aspectos que não poderão ser apresentados aqui, os espaços de poder de tons patriarcais mostraram-se definitivamente falíveis. Apesar de o rei ter estado $n u^{2}$ antes mesmo da guerra, a conjugação simbólica ficcional em torno dele permitia a negação de tal evidência e o reconhecimento e a eficácia do posto soberano. Com ela, porém, a nudez se apresenta em toda sua crueza, mas a vulnerabilidade de tais estruturas ainda não pode ser psíquica e socialmente elaborada - daí a melancolia perdurar. Ou seja, se insistimos nesses mesmos modelos ainda hoje, é por uma espécie infindável de compulsão à repetição desencadeada pelo impacto traumático que gera um torvelinho e nos carrega para um buraco sem fim. Como bem precisou Walter Benjamin (1940/2005), tal abismo tem recebido o nome de progresso.

É mesmo uma questão se algum dia a impermanência de todas as coisas será admitida por sujeitos que idolatram totens e que têm ocupado invariavelmente importantes lugares de poder. Muitos estão de corpos presentes na atualidade, enquanto seus espíritos vagam por outras épocas, outras configurações, outros espaços. Não se pode arrastá-los à força para engendrar moldes que seriam mais condizentes com o momento atual. Por isso, convive-se com zumbis, melancólicos inveterados.

$\overline{2}$ Agradeço mais uma vez Lívia Santiago pela indicação da metáfora. 


\section{O erotismo da unicórnia preta}

O poder do erotismo pairava sobre minhas reflexões de modo impreciso, até Lívia Santiago indicar-me a leitura de Os usos do erótico: o erótico como poder ${ }^{3}$. Trata-se de uma transcrição da fala de Audre Lorde (1995) que busca diferenciar o erotismo da pornografia, mostrando como ele é um recurso poderoso e disponível para as mulheres, atacado e depreciado ao longo da história. Embebida da leitura de Audre Lorde, li casualmente o manifesto Chega de melancolia!, de Larissa Drigo (2018). Surpreendentemente encontrei ali uma referência ao poema $A$ unicórnia preta, também de Audre Lorde, comentado pela autora:

A unicórnia preta é ávida/a unicórnia preta é impaciente/a unicórnia preta foi confundida/com uma sombra/ou símbolo/e levada/ através de um país gelado/onde a névoa fez um retrato risível/da minha raiva./Não é em seu colo onde o chifre repousa/mas nas profundezas de sua cratera lunar/crescente/a unicórnia preta é inquieta/a unicórnia preta é implacável/a unicórnia preta não é/livre. (Lorde, 1995, p. 3)

Assumir um eu lírico sob forma de unicórnia preta é desestabilizar o próprio lugar de enunciação de um eu lírico e os modos de subjetivação a ele atrelados - inumana, mágica e ficcional, a unicórnia preta existe apenas nas letras do poema. Repleta de energia vital, ela é ávida e impaciente. Antes mesmo de assumir seus passos concretos e respirar o ar que nos rodeia, a unicórnia preta foi petrificada como sombra ou símbolo. Sua vitalidade inquieta e implacável, cheia de calor raivoso e potente, foi conduzida a um país gelado, capaz de apagar a chama que se mantinha à flor de sua pele. Sua liberdade ainda é, por conseguinte, apenas uma promessa.

Importante notar que o erotismo, reativado pelo feminismo negro e pela teoria queer, não se limita à libertação sexual, tal como advogada pelas feministas liberais. Quando a unicórnia preta ultrapassar as letras do belo poema e do registro fantástico ao qual está confinada, ela colocará os pés em outra estrutura de poder econômico e político. Por isso, seu espaço surrealista e sua designação absurda não indicam, como se po3 A indicação de tal leitura surgiu após os debates realizados no GEPEF (Grupo de estudos, pesquisas e escritas feministas). 
deria supor, um desajuste de suas formas extravagantes que deveriam ser remodeladas para caberem na estrutura existente. O que casos recorrentes de exceção à regra demonstram é a totalidade do fracasso das estruturas nas quais estamos inseridos. Como se sabe, embora mulheres e homens negros e outros sujeitos, cujas orientações sexuais não se conformam aos moldes cisgênero, componham grande parte do espectro de sujeitos que integra toda a massa humana, os moldes jurídicos, políticos e econômicos ainda estão configurados em zonas normativas heterossexuais, brancas e patriarcais, exigindo a conformação de todos os demais. Com a unicórnia preta, Audre Lorde cria uma figura da inadequação e afirma sua possibilidade concreta de existência quando os contornos forem dados dentro de horizontes que afirmem a vida de todos, sem exceção.

Nas palavras de Larissa Drigo: “[...] há um grande perigo que ameaça os unicórnios, eles podem ser tomados por símbolos, podem se confundir com as sombras, e, por que não com fantasmas, e, assim, capturados, continuam a não ser livres" (2018, p. 21). Unicórnias pretas são a paradoxal designação do inexistente - o fantástico que estremece afetos, embaralha categorias prévias de entendimento, sacode o espírito e faz vibrar o corpo erótico exigindo uma espacialidade concreta capaz de abarcá-lo.

"A sombra do objeto recai sobre o próprio eu", disse certa vez Freud (1917/2010) para descrever a melancolia. Hans Loewald (1998) inverte a frase para tratar do processo sublimatório: "A sombra do eu recai sobre o objeto". A sublimação é efeito da dessexualização da libido ou do desvio do objeto de desejo em nome de algo mais elevado. Pouco importa se na versão melancólica ou se na sublimatória, o fato é que alguma espécie de fixidez imagética perpassa esses processos psíquicos - de um lado é a imagem do objeto que assola o eu, do outro é o reflexo do eu a enterrar e colonizar o objeto. Duas formas fracassadas de lidar com angústias e desejos. A sombra de um objeto sobre o eu ou a do eu sobre o objeto serve para acinzentar tudo, mortificar as variações de cores e luzes, curvar o corpo e tolher o frêmito dos órgãos, embotar o erotismo e entristecer os movimentos do 
espírito. À sombra e à imagem faltam corpo erótico e vibração afetiva. São reflexos desbotados da carne. Daí o poema de Fernando Pessoa, evocado em Chega de melancolia!:

Ah, tudo é símbolo e analogia!/O vento que passa, a noite que esfria/São outra cousa que a noite e o vento - / Sombras de vida e de pensamento./Tudo que vemos é outra cousa./A maré vasta, a maré ansiosa,/É o eco de outra maré que está/Onde é real o mundo que há./Tudo que temos é esquecimento./A noite fria, o passar do vento/São sombras de mãos cujos gestos são/A ilusão mãe desta ilusão. (apud Drigo, 2018, p. 23)

Nesse ponto, talvez seja importante retomar uma questão que foi colocada de modo certeiro por Lívia Santiago:

[...] por que com toda a tecnologia disponível para a criação das mais diversas imagens e mundos, não conseguimos deixar de imaginar que o único destino seja a catástrofe? Para Phillips (2016), se a única resposta possível é a catástrofe, está faltando uma outra teoria, uma outra ficção. Após toda a crítica ao Complexo de Édipo da psicanálise, não conseguimos escapar da lógica paternalista do reconhecimento? Ainda retornamos voluntariamente à lógica da culpa, da punição, da tirania e do excesso violento. Como nos mostram os personagens sobreviventes de hecatombes planetárias, até nos gêneros de fantasia e ficção científica não conseguimos conceber outra lógica de poder, a exemplo dos múltiplos filmes e séries de cenários pós-apocalípticos que têm sido revisitados e produzidos em escala dominante na indústria cultural. (Santiago, 2018, p. 316)

O que Santiago denomina lógica paternalista, que estaria sob a égide do complexo de Édipo, não seria justamente uma maneira sempre repetitiva de estabelecer formas simbólicas pela via da fixidez de imagens mortas - os totens, o poder soberano nos estados-nação, o Capital?

É curioso que Freud tenha escrito seu belo texto Sobre a transitoriedade em 1915 e, pouco depois, tenha se dedicado às bases que estariam envolvidas nos processos psíquicos da melancolia, isto é, do sujeito que justamente não é capaz de aceitar a fragilidade e a efemeridade da vida e de seus objetos de amor e desejo. Temos, aqui, dois registros de temporalidade: um deles contempla o caráter contingente dos acontecimentos e a transitoriedade de todas as coisas existentes; o outro retém até engessar o objeto ou o plasma dele em contornos imóveis, 
que emergem como reflexos especulares do eu estagnado e a ele submetido. Sublimação e melancolia andam de mãos dadas, uma é a forma simbólica da outra. Culpas e ideais assolam e asfixiam o melancólico. No lugar delas, apresentam-se dois antídotos: o vibrante erotismo e a intensidade afetiva.

\section{Um basta à melancolia}

Foi um trecho preciso de Chega de melancolia! que ecoou até reacender a frase "na esfera atual [...], o melancólico - ou o depressivo - seria um ser anacrônico". Ânimo comum entre modernos, a melancolia, explica Larissa Drigo, foi tomada por Edgar Allan Poe como afeto de orientação de seus poemas por só ele ser "capaz de agradar tanto aos críticos quanto aos leitores 'menos exigentes"'. A autora insiste que a história como sucessão de tragédias - de sucessos e fracassos, de vencedores e vencidos - faz de cada sujeito um desolado viúvo, entorpecido pela melancolia. Nas palavras da autora:

[...] Poe explica, em sua Filosofia da composição, que escolheu esse afeto, esse sentimento para seu poema, a melancolia, porque era capaz de agradar tanto aos críticos quanto aos leitores "menos exigentes". Não estaria ele nos dizendo que em seu tempo a melancolia era um afeto constituinte do senso comum? Um senso comum que transforma a história em uma sucessão de tragédias e os sujeitos em viúvos inconsoláveis tomados por uma paralisante melancolia? (Drigo, 2018, p. 21).

Em seu tempo é a expressão que nos interessa aqui. Sim, no tempo de Edgar Allan Poe a melancolia era parte do senso comum e agradava tanto ao público em geral quanto aos leitores especializados. Um afeto acinzentado que pairava como bruma sobre a modernidade. É esse tempo, que namora a melancolia, a ainda persistir compulsivamente por meio da identificação afetiva ${ }^{4}$ com os vencedores de plantão, diz Walter Benjamin (1940/2005) em Sobre o conceito da história. Sua origem é, afirma ainda o filósofo, "a indolência do coração, a acedia, que he-

$4 \quad$ Essa tradução convém para minhas análises, mas é imprecisa. A expressão em alemão é Verfahren der Einfühlung que dificilmente pode ser traduzida por identificação afetiva - a versão mais próxima seria processo de empatia ou mecanismo da empatia. 
sita em apoderar-se da imagem histórica autêntica que lampeja fugaz". (p. 70). Troca-se, uma vez mais, a fagulha da diferença, que se apresenta de forma efêmera e revolucionária no instante-de-agora [Jetztzeit] em meio às camadas do passado, pela fixidez de um objeto moribundo, com o qual haveria uma identificação empática capaz de preservar lugares, cristalizar velhos moldes e normatividades fracassadas. A este respeito, lemos:

No lugar da história tecida pelos fios de vencedores e vencidos ou, ao invés da escolha por "lutar para vingar os antepassados escravizados ou trabalhar para libertar as gerações futuras (arbeit macht frei), pode[-se] dar lugar a uma outra [história], em que não se trata de sucesso ou derrota, mas de verdadeira firmeza e valor". (Drigo, 2018, p. 27).

É nesse contexto de afirmação da firmeza e do valor como indicativos de um outro horizonte para percorrer a história que Drigo recupera o ímpeto das bravas palavras finais do diário de Kafka: "Melhor do que oferecer um consolo, eu acrescento, melhor que lutar contra ou pelo esquecimento, seria poder dizer: você também tem armas!".

$*$

Que armas seriam estas? Antes de responder à questão, façamos uma breve digressão para que alguns fios possam ser alinhavados aqui e ali. Quando uma psicanalista se insere num universo de debates feministas e da teoria queer, as tensões entre sua formação no campo psicanalítico e os impasses levantados pelas mulheres e queers começam a embaralhar organizações gramaticais, até que um profundo tremor exige uma recolocação das próprias questões que moveram os fundadores da psicanálise. A leitura de Os usos do erótico: o erótico como poder provoca esse tipo de abalo sísmico de grande magnitude. O que emerge, então, é o recalque do erotismo como recalque de uma história de traços tradicionalmente cultivados entre mulheres um processo civilizatório obsessivo e melancólico, que amputa o corpo erótico e impermanente como potência.

O inconsciente é a histérica, mulher que deseja explorar o erótico, mas não encontra canais sociais através dos quais possa lhe dar vazão. Domado pelos moldes melancólicos e ob- 
sessivos, o corpo da histérica converte o erotismo em signo de uma insatisfação com as regras e normas sociais. Em sua versão difamada, o erótico é colocado contra as mulheres. É comparado ao pornográfico, diminuído como algo vil. O erotismo, porém, pertence àquilo que nos governa de maneira mais decisiva - o inconsciente. Quando conduz a vida, o erotismo segue um percurso de liberdade e satisfação pouco condizente com as amarras obsessivas e melancólicas da cultura patriarcal.

A psicanálise foi perspicaz ao reconhecer a força do erótico na vida humana; uma história submersa, cuja intensidade e cujo vigor atemporal são capazes de determinar decisivamente a superfície consciente. Freud abriu brechas para que ele pudesse escapar e existir. Entretanto, dosou seu gesto revolucionário amputando o erótico para que ele coubesse em um modelo civilizatório que ele mesmo admitia ser extremamente limitado. Em outras palavras: se Freud foi sagaz ao perceber a faceta opressiva do recalque na recusa do erótico, ele só admitiu sua expressão no interior de uma estrutura civilizatória orientada por vias repressivas ou por consolos sublimatórios. Só depois, isto é, só após o sujeito garantir sua neurose, ele poderá, finalmente, dar um pequeno espaço aos traços do desejo - sublimando-os ou vivendo-os de forma tímida e apenas pelas bordas, como restos.

Freud iniciou suas investigações psicanalíticas a partir de sua teoria da sedução. Abandonou-a para introduzir a realidade psíquica - ele já não acreditava na verdade proferida pelas mulheres histéricas. Deu preferência às sombras fantasmáticas, ao universo mental das fantasias, à universalidade abstrata do complexo de Édipo, aplicado a torto e a direito. Se tivesse acreditado até o fim no que elas diziam, porém, qual a verdade que poderia estar contida em suas palavras? Talvez não fosse o evento efetivo de um abuso o que as traumatizasse, mas o efeito concreto de uma leitura equivocada - explorando o erotismo, eram interpretadas como oferecidas, pornográficas, sedentas de abuso sexual. Sim, pois na era em que houve o advento da psicanálise, conformou-se um destino específico para as mulheres burguesas: o lar e o cuidado das crianças. 
"Elas queriam ser abusadas" ou "elas se ofereceram e mereciam ser estupradas" - não são frases como essas as que escutamos, ainda hoje, quando andamos livremente e alegres pelas ruas? Quando nossos afetos transbordam e o erotismo impregna nossos gestos mais sutis não somos imediatamente perturbadas com olhares que exigem contenção, compostura, comedimento? Não seria a liberdade do erotismo aquilo que as histéricas efetivamente reivindicavam? A insuficiência de tudo não é a insuficiência mesma de moldes civilizatórios burgueses, tão acinzentados e exânimes? Tão recobertos de nuvens e vazios de corporeidade? Tão afeitos às abstrações universalizantes e apartadas da materialidade carnal?

Erotismo é poder, defende Audre Lorde. De acordo com a autora, trata-se de uma espécie de engenho "feminino e espiritual" que ainda se mantém sufocado. Quando a potência de um recurso é capaz de abalar os poderes instituídos, ele emerge numa versão distorcida para que sua força se enfraqueça e a opressão se perpetue. Repertórios e artifícios capazes de transformar bases engessadas de poderes que perduram tornam-se, em suma, alvos de ataques. Assim, suprimir o erótico é uma estratégia de guerra contra as mulheres. Um meio de minar substratos de poder e conhecimentos próprios à cultura que tradicionalmente as formou. Sempre que brotou, o erótico foi caluniado, insultado e desvalorizado pelos representantes da sociedade do patriarcado ocidental. Tido como signo de superficialidade mercadológica e de inferioridade cognitiva, o erótico tornou-se elemento desprezível e suspeito entre todos os nobres cidadãos. Convencidas do caráter condenável do erotismo, mulheres esforçaram-se por escondê-lo, abafá-lo, eliminá-lo. O erotismo como poder só pode passar ao crivo social quando maquiado no interior dos moldes masculinos de poder. Não raro, ele se torna condenável ao ser transfigurado por um discurso que o iguala à pornografia.

Os homens sabem do valor inerente ao erotismo e mantêm essa qualidade sob seu domínio e em seu benefício - quando presta-se a servi-los, o erotismo pode ser explorado por e para eles. A desconfiança das mulheres em relação ao saber e ao po- 
der ligados ao erotismo é algo incorporado ao longo da vida, quando elas são continuamente alertadas sobre os perigos e malefícios de usá-lo. Entretanto, diz Lorde, "o erótico oferece um manancial de força revigorante e provocativa à mulher que não teme sua revelação, nem sucumbe à crença de que as sensações são o bastante" (p. 1). Daí que a contundência de Lorde não poderia ser menor: "uma vez tendo vivido a completude dessa profundidade de sentimento e reconhecido seu poder, não podemos, por nossa honra e respeito próprio, exigir menos que isso de nós mesmas". Segue-se a isso, palavras ainda mais contundentes:

Nunca é fácil demandar o máximo de nós mesmas, de nossas vidas, de nosso trabalho. Almejar a excelência é ir além da mediocridade incentivada por nossa sociedade. Mas sucumbir ao medo do sentimento e trabalhar no limite é um luxo que só pode se permitir quem não tem aspirações, e essas pessoas são aquelas que não desejam guiar seus próprios destinos. Mas a demanda íntima pela excelência que aprendemos do erótico não pode ser mal-entendida como exigir o impossível nem de nós mesmas nem das outras. Tal exigência incapacita todo mundo no processo. Porque o erótico não é sobre o que fazemos; é sobre quão penetrante e inteiramente nós podemos sentir durante o fazer. E uma vez que saibamos o tamanho de nossa capacidade de sentir esse senso de satisfação e realização, podemos então observar qual de nossos afãs vitais nos coloca mais perto dessa plenitude. (Lorde, 1995, p. 1)

Sem o erotismo, resta o desvitalizado estado melancólico em sua imersão solipsista. Áreas vigorosas são comprimidas. No lugar delas, dá-se vazão a raciocínios puramente abstratos e ruminações infindáveis com tonalidades lúgubres. Eles destituem o lugar de saber do corpo, da sensorialidade, da sensualidade. O lucro ou a mais-valia como articulação do sistema em lugar das necessidades e dos desejos humanos elimina o valor erótico do trabalho - rouba-lhe a vibração da vida. Oprimir o erótico e exaltar a necessidade do trabalho para obtenção de um mero ganha-pão "é o mesmo que cegar uma pintora e dizer a ela que melhore sua obra, e ainda que goste de pintar, isso não é só perto do impossível, é também, profundamente, cruel". (Lorde, 1984, p. 2).

Como mulheres, a exigência não pode ser menor do que a de transformar os fundamentos da vida política e social. Eros como amor não está apartado do âmbito político. Afetos e ero- 
tismo não estão confinados à vida privada - com eles, move-se uma engrenagem enferrujada e pode-se mudar a direção para a qual ela está programada. O erotismo penetra como oxigênio nas zonas mortas, nos interstícios de tecidos cadavéricos daquilo que se toma como naturalmente dado em instâncias necrofílicas de poder.

A tentativa frequente de equiparar a pornografia ao erotismo, identificada por Lorde, nada mais é do que a tentativa de mortificar o erotismo em corpo-objeto ou em mero reflexo do desejo - desnutrir o desejo até suprimir toda sua vitalidade. "Separar o espiritual do erótico" significa reduzir, diz Lorde, "o espiritual a um mundo de afetos insípidos, do asceta que deseja sentir o nada" (p. 2). O espiritual, destituído de corpo, afasta-se da verdade, pois "a posição ascética é uma [defesa] do mais grandioso medo, da mais extrema imobilidade". Ainda nas palavras da escritora caribenha-americana: "a abstinência severa do asceta torna-se a obsessão dominadora. E não é uma que se embase na autodisciplina, mas sim na abnegação". (p. 2)

Assim, o elo entre o espiritual e o político é erótico e sensual. Partilha de gozo físico, afetivo, psíquico ou intelectual, que diminui o medo de diferenças e deposita colorido sobre as relações sociais. Amplia-se de maneira franca e corajosa a capacidade de gozar. O corpo "se expande com a música, se dilatando em reação a ela, escutando seus ritmos profundos" (p. 3) e, da mesma forma, o erotismo dilata a experiência, seja ela a de dançar, a de ler, a de escrever um poema ou a de examinar uma ideia. Injetar afetos vigorosos e eróticos em cada coisa experimentada não precisa condizer com ideias de "casamento, nem deus, nem vida após a morte". (p. 3).

Se o erotismo é tão temido é porque só ele é capaz de expandir afetos e relações, penetrar diferenças, almejar a multiplicidade, romper as barreiras da propriedade privada que moldam, inclusive, filigranas de uma subjetividade possessiva. Dentro do quarto e de maneira comedida, o erotismo pode existir, mas estará condenado, embotado e reduzido ao campo privado conquistado por certos homens. 
Quais recursos seriam capazes, então, de reconfigurar a história? Em termos psicanalíticos: que traços de memória ou inscrições mnêmicas deveriam ser resgatados no presente até remodelar as estruturas sociais pelo erotismo nelas injetado? Traços mnêmicos apelam por uma remodelação do presente e, por isso, deveriam inflamar o desejo, aguçar corpo e mente, atiçar a vontade e a sede de viver de maneira venturosa:

Reconhecer o poder do erótico em nossas vidas pode nos dar a energia necessária para fazer mudanças genuínas em nosso mundo, mais que meramente estabelecer uma mudança de personagens no mesmo drama tedioso. Pois não só tocamos nossa fonte mais profundamente criativa, mas fazemos o que é fêmeo e autoafirmativo frente a uma sociedade racista, patriarcal e anti-erótica. (Lorde, 1995, p. 4).

\section{Eros e Thanatos: uma velha questão freudiana}

Do erotismo é possível dizer que ele é a aprovação da vida até na morte. Para falar a verdade, isto não é uma definição, mas eu penso que esta fórmula dá o sentido do erotismo melhor que uma outra. George Bataille

É tentador embarcar no mais genuíno entusiasmo em favor do erotismo contra os cadáveres melancólicos, tão encharcados de pulsão de morte. Contudo, seria também ingenuidade estabelecer uma fronteira intransponível entre aspectos mortíferos e eróticos. Dicotomia fácil, quase um apelo para a pueril divisão entre bem e mal.

Freud debateu o tema e o formalizou em Além do princípio do prazer. Em Erotismo, George Bataille radicalizou a porosidade entre prazer erótico e morte: a atividade erótica como exuberância da vida, diz ele, não é estranha à morte. Freud (1920/2010), porém, não renunciou ao caráter conflitivo das pulsões. Chega a recobrar a filosofia de Schopenhauer, "para quem a morte é 'o autêntico resultado' e, portanto, o objetivo da vida, enquanto o instinto sexual é a encarnação da vontade de vida". (p. 220). 
O conflito entre Eros e Thanatos, apresentado por Freud em Além do princípio do prazer, parece ser a rota da qual seria impossível desviar para adentrar algumas camadas mais densas do debate que apresentei anteriormente. Ao reler o clássico texto freudiano, nota-se uma matéria subjacente que não é visivelmente explorada pelo pai da psicanálise: o caráter cultural e sócio-histórico da pulsão de morte.

Talvez valesse a pena refletir sobre a maneira a partir da qual muitos psicanalistas pensam o texto Além do princípio do prazer. É assaz comum vê-lo interpretado como expressão e reunião de ideias e conceitos latentes, que só estavam à espera de uma espécie de amadurecimento intelectual-afetivo do mestre para obterem suas condições de redação. É certo que o trabalho que marcou a mais importante inflexão na obra freudiana não deixa de ser situado historicamente entre pesquisadores. O viés histórico, no entanto, participa perifericamente, quase como uma convenção inescapável ao campo da erudição acadêmica. A chave de leitura em geral, porém, é a de uma complexificação do prisma conflitivo do aparelho psíquico em relação àquele mais comum de que se dispunha antes: pulsões sexual e de autoconservação.

Uma leve modificação dessa leitura pode ser profícua para reflexões acerca do erotismo e do caráter mortífero da melancolia. Tentaremos demonstrar que, se a faceta mortífera da existência humana é elemento a ser seriamente levado em conta, ela não opera necessária e naturalmente em toda sua intensidade compulsiva, tal como a vemos operar da modernidade em diante. A pulsão de morte certamente sempre esteve presente, mas só ganhou consistência expressiva até moldar as entranhas de todos os modos de vida concretos após a Primeira Guerra Mundial. Ou seja, a pulsão de morte não está entranhada em nossas vísceras, tal como Freud pretendeu em 1920.

Os estímulos de prazer e desprazer evocados em Além do princípio do prazer são excitações intensas, perturbações que desestabilizam o sistema psíquico em contínua busca para manter o equilíbrio. O paradoxo é que, se as excitações são ameaçadoras, a manutenção que perpetua o equilíbrio também 
conduz a uma espécie de ameaça. De um lado, o estímulo perfura a superfície protetora do aparelho, estremecendo todo o fluxo corriqueiro que o ordenava; de outro, o sistema mantido sempre igual tende a um estado inorgânico, tocando as margens da morte.

Freud repara que a intensidade excitatória suscita "terror", "medo" ou "angústia". Quando o perigo se apresenta, o sujeito responde a partir de alguma dessas manifestações subjetivas. Enquanto à "angústia" refere-se a expectativa e a antecipação imaginária do perigo, ao "medo" liga-se um determinado objeto capaz de provocá-lo [Angst von etwas]. No terror, por sua vez, a ameaça se apresenta de modo repentino, sem que se esteja para ela preparado. $\mathrm{O}$ fator surpresa e o terror seriam decisivos para a experiência traumática.

Tanto a neurose traumática como a de guerra são desencadeadas por uma inesperada cena terrível que emerge diante do sujeito. Entretanto, os desdobramentos de uma e de outra são diversos - os efeitos da neurose traumática articulam-se como defesas intrapsíquicas, ao passo que na neurose de guerra o efeito do impacto é perceptível para um observador de fora - talvez tenha sido justamente a expressão visível da pulsão de morte, invocada pelo terror da guerra, a colocar Freud frente a frente com o problema econômico do aparelho psíquico, rearticulado por esse trauma da guerra em especial.

Seja como for, Freud afina a distinção entre esses elementos a partir da metáfora da vesícula viva, delineando o que estaria em jogo no aparelho psíquico e na esfera dos diferentes traumas que impelem o sujeito a uma compulsão à repetição. Quase uma ameba - a imagem é curiosamente destituída de erotismo -, tal organismo vivo seria composto de substâncias excitáveis e sua superfície seria uma espécie de órgão receptor de estímulos. Choques oriundos do mundo externo, que atingem essa camada superficial da vesícula, acabam por alterar sua composição material até modificá-la em relação ao que se preserva em seu interior. Forma-se, então, uma casca curtida pela força contínua de servir como obstáculo aos estímulos. Ela protege o organismo e o mantém intacto. Nas palavras de Freud: 
[...] o pequeno pedaço de substância viva flutua num mundo externo carregado de fortes energias, e seria liquidado pela ação dos estímulos que vêm dele se não fosse dotado de uma proteção contra estímulos. Ele a adquire da forma seguinte: sua superfície mais exterior perde a estrutura própria do que vive, torna-se inorgânica em certa medida, e funciona como um invólucro ou membrana especial que detém estímulos, isto é, faz com que as energias do mundo exterior possam penetrar com uma fração de sua intensidade nas camadas adjacentes, que permaneceram vivas. (Freud, 1920/2010, p. 188).

Atenuados, os estímulos que conseguiram passar pela camada são transportados e religados. A camada calejada e morta preserva formas já existentes de funcionamento do organismo e nivela a energia que poderia ser despertada da intensidade dos estímulos externos. Se a casca impede ou dificulta a intrusão de estímulos externos no sistema, tal superfície protetora não pode impedir que os estímulos internos operem com uma força também desestabilizadora de toda a vesícula. A intensidade embaralha a energia e as ligações que a mantinham estável. Em suma: por um lado, há algo que se coloca contra o que sobrevém do exterior e reduz os efeitos dos estímulos externos, por outro a proteção é inexistente em relação aos estímulos que emergem do interior e aparecem sob forma direta, não atenuada no sistema. Neste caso, as excitações de camadas mais profundas se propagam e produzem uma série de sensações de prazer-desprazer.

Diante de tais articulações metapsicológicas, queremos chamar atenção para algo bastante específico a ser demonstrado em quatro camadas: a economia psíquica que rege a teoria das pulsões em termos puramente quantitativos não é capaz de se sustentar, sem que o próprio Freud se traia por um viés qualitativo entranhado na distribuição energética de prazeres e desprazeres. É o pai da psicanálise a admitir um teor qualitativo capaz de diferenciar os estímulos oriundos do interior daqueles que sobrevêm do exterior. Seguindo sua lógica, percebe-se que aquilo que sobrevém de dentro é qualitativamente diverso daquilo que aparece de fora. De certa maneira, é menos surpreendente, o que, por conseguinte, torna a matéria interna menos terrível do que são os estímulos oriundos do exterior. Em seus termos: "Sem dúvida, as excitações vindas de dentro 
serão, por sua intensidade e por características outras, qualitativas, [...] mais adequadas ao modo de funcionamento do sistema do que os estímulos provenientes do mundo exterior". (Freud, 1920/2010, p. 191).

Ora, se há uma qualidade entre estímulos que incidem sobre o sistema desde dentro e aqueles que o invadem de fora, não seria também pertinente distinguir qualitativamente o teor das próprias excitações que atravessam a barreira do sistema desde fora? Explico melhor: Freud abstrai o conteúdo das excitações fazendo delas intensidades quantitativas de estímulos, das quais o aparelho se protege, seja isolando-as para atenuar sua força por meio de contra-investimentos, seja religando-as em aspectos que estavam disponíveis no interior do sistema. Contudo, quero sugerir aqui que se há algo capaz de diferenciar qualitativamente o que incide de fora daquilo que incide de dentro, não é fora de propósito pensar que também seria importante avaliar qualitativamente cada um dos estímulos que afetam o aparelho e causa terror.

Há um segundo ponto a ser notado na mesma direção: Freud considera que um sistema que dispõe de recursos mais sofisticados absorve mais facilmente a nova energia, ligando-a psiquicamente. Aqui, à semelhança do que vimos sobre a faceta valorativa das excitações internas e externas, também se observa uma distinção qualitativa a respeito de sistemas díspares. Ou seja, há sistemas mais dotados de artifícios que outros e que estão melhor preparados para lidar com as invasões energéticas que incidem sobre o aparelho psíquico. Numa palavra: há sistemas qualitativamente melhores para abarcar o impacto do que outros. Mais uma vez, o viés puramente econômico da teoria pulsional freudiana revela-se inarredável de conteúdos valorativos específicos.

Um terceiro movimento de reconhecer a qualidade imanente à distribuição da quantidade pulsional emerge em Sol negro, de Julia Kristeva (1998). Curiosamente, citando Freud, a autora lembra que a melancolia narcísica manifestaria a pulsão de morte no seu estado de desunião com a pulsão de vida, acrescentando que "o superego do melancólico aparece para 
Freud como "uma cultura da pulsão de morte"'s (p. 162). O elemento cultural da pulsão de morte observado na melancolia também a retira de sua conotação meramente energética quantitativa, mostrando que a própria pulsão de morte pode ser cultivada, como fazem os espíritos melancólicos.

Vejamos ainda uma quarta e última etapa das linhas culturais que atravessam as pulsões. Em Além do principio do prazer, Freud retoma a tese de Kant, segundo a qual tempo e espaço moldam as primeiras condições de possibilidade da razão. Opõe-se à tese do filósofo dizendo que os processos psíquicos inconscientes são "atemporais" em si. Tais processos não seriam, por conseguinte, ordenados temporalmente e a passagem dos dias em nada alteraria as marcas impressas no inconsciente. Nas letras de Freud (1920/2010): "a ideia de tempo não [...] pode ser aplicada [aos processos psíquicos]" (p. 190). Os traços inconscientes seriam, por conseguinte, negativos e acessíveis apenas quando cruzados aos processos psíquicos conscientes. Entretanto, a questão que se coloca mais uma vez diz respeito à qualidade de tais cruzamentos entre passado atemporal, cujas marcas seriam negativas, e presente dos conteúdos conscientes, aptos a concederem materialidade aos aspectos inconscientes. Por mais que as inscrições mnemônicas sejam negativas e inapreensíveis em seu conteúdo original o modo ou a qualidade daquilo que fez marca é fundamental para outro parti pris da psicanálise: o determinismo psíquico. Ou seja, nunca é aleatório, de acordo com Freud, que um conteúdo específico nos fisgue em detrimento de outros. Ora, se assim é, algo qualitativo subjacente está necessariamente em jogo nessa construção meramente energética - o fragmento do presente tem caraterísticas específicas que convocam determinados traços mnêmicos que resguardam semelhanças qualitativas com aqueles.

Não é necessário, contudo, apelar apenas às nossas elucubrações para demonstrar o caráter qualitativo das pulsões,

$5 \quad$ No alemão, o que se encontra é a seguinte frase no capítulo $\mathrm{V}$ de Das ich und das es: "Was nun im über-Ich herrscht, ist wie eine Reinkultur des Todestriebes, und wirlich gelingt es diesem of genug, das Ich in den Tod zu treiben, wenn das Ich sich nicht vorher durch den Umschlag in Manie seines Tyrannen erwehrt." 
atrelado a aspectos históricos e culturais. O próprio Freud admite tal faceta em $O$ problema econômico do masoquismo ao dizer:

Será lembrado que entendemos o princípio que rege todos os processos psíquicos como um caso especial da tendência à estabilidade proposta por Fechner, e portanto atribuímos ao aparelho psíquico a intenção de reduzir a nada a quantidade de excitação que lhe chega, ou, ao menos, mantê-la a mais baixa possível. Barbara Low sugeriu, para essa suposta tendência, o nome de princípio do Nirvana, que nós aceitamos. Mas apressadamente identificamos o princípio de prazer-desprazer com este princípio do Nirvana. Assim, todo desprazer deveria coincidir com uma elevação, e todo prazer com um abaixamento da tensão devida a estímulos que se acham na psique; o princípio do Nirvana (e o do prazer, supostamente idêntico a ele) estaria totalmente a serviço dos instintos de morte, cuja meta é conduzir a vida sempre instável à quietude do estado inorgânico, e teria a função de advertir contra as exigências dos instintos de vida, da libido, que buscam perturbar o pretendido curso da vida. Mas tal concepção não pode ser correta. Ao que parece, sentimos o aumento ou decréscimo dos montantes de estímulos diretamente na série dos sentimentos de tensão, e não há dúvida de que existem tensões prazerosas e distensões desprazerosas. O estado de excitação sexual é o mais claro exemplo de um aumento de estímulos assim prazeroso, mas certamente não é o único. Prazer e desprazer, portanto, não podem ser referidos ao aumento ou diminuição de uma quantidade que chamamos de tensão devida a estímulos, embora claramente tenham muito a ver com isso. Parece que não dependem desse fator quantitativo, mas de uma característica dele que só podemos designar como qualitativa. Estaríamos bem mais adiantados na psicologia, se soubéssemos indicar qual é esse traço qualitativo. Talvez seja o ritmo, o transcurso temporal das mudanças, elevações e quedas da quantidade de estímulos; não o sabemos. (Freud, 1924/2011, p. 185-7)

Como vimos, Freud só foi capaz de conceder configurações mais precisas à pulsão de morte em 1920, isto é, após uma certa qualidade de experiências traumáticas com a guerra de dimensão global ser colocada em ação por meios técnicos inéditos. Não seria, portanto, pertinente pensar que uma atmosfera moribunda e melancólica atravessava sobremaneira a Europa, após as tensões e disputas latentes entre estados-nação europeus terem emergido por meio de combates atrozes, fortes o suficiente para lançarem no limbo quase todas as apostas iluministas anteriores? Uma cultura da pulsão de morte não teria ficado definitivamente exposta com a guerra imperialista e suas consequências? Uma tendência inelutável à restauração de um estado anterior, à inércia própria ao estado inorgânico não aba- 
teria qualquer um de nós naquelas condições socio-históricas e culturais específicas?

Se esse prisma é considerado e aberto em Além do princípio do prazer, temos inclusive uma nova perspectiva sobre o contínuo recrudescimento da pulsão mortífera pré-guerra como os processos de opressão e dominação colonial imperialista e seus desdobramentos nos nazifascistas pós-guerra. Sim, pois Freud observa o caráter conservador das pulsões e sua orientação para a regressão como algo imanente a elas, isto é, como se elas assim se movessem de maneira natural. Como já admitimos, não resta dúvida que também haja um viés mortífero inerente à existência humana, mas talvez coubesse considerar que a pulsão de morte prepondera de modo exacerbado, orientando configurações políticas, práticas e simbólicas apenas quando o sistema está efetivamente diante de uma certa qualidade específica de excitações, como foram as vividas naquele período. $\mathrm{O}$ impacto da Grande Guerra ordenou e ainda ordena toda sorte de acontecimentos que a ele se desdobraram. É o que fica claro em estudos contemporâneos, sobretudo quando se considera as teses de Achille Mbembe (2016) em Necropolítica, das quais extraio uma importante passagem:

Tomando uma perspectiva histórica, um número de analistas tem argumentado que as premissas materiais do extermínio nazista podem ser encontradas no imperialismo colonial, por um lado, e, por outro, na serialização de mecanismos técnicos para conduzir as pessoas à morte - mecanismos desenvolvidos entre a Revolução Industrial e a Primeira Guerra Mundial. Segundo Enzo Traverso, as câmaras de gás e os fornos foram o ponto culminante de um longo processo de desumanização e de industrialização da morte, entre cujas características originais estava a de integrar a racionalidade instrumental com a racionalidade produtiva e administrativa do mundo ocidental moderno (a fábrica, a burocracia, a prisão, o exército). Um traço persiste evidente: no pensamento filosófico moderno e também na prática e no imaginário político europeu, a colônia representa o lugar em que a soberania consiste fundamentalmente no exercício de um poder à margem da lei (ab legibus solutus) e no qual tipicamente a "paz" assume a face de uma "guerra sem fim". Poderíamos pensar que as ideias recém-desenvolvidas dizem respeito a um passado distante. No passado, com efeito, guerras imperiais tiveram como objetivo destruir os poderes locais, instalando tropas e instituindo novos modelos de controle militar sobre as populações civis. Um grupo de auxiliares locais podia participar da gestão dos territórios con- 
quistados, anexados ao Império. Dentro do Império, as populações vencidas obtinham um status que consagrava sua espoliação. Em configurações como essas, a violência constitui a forma original do direito, e a exceção proporciona a estrutura da soberania. (Mbembe, 2016, p. 129)

Essa perspectiva claramente abala a afirmação que viria da pena de Freud (2010) em 1920: "querer restaurar um estado anterior é realmente uma característica universal dos instintos". Voltando à conotação qualitativa da pulsão de morte, teríamos que admitir a existência de uma vibração intensa que se propaga historicamente de maneira destruidora e mortífera no patriarcado supremacista branco e heteronormativo, paulatinamente desenvolvido na modernidade europeia. Algo que ainda insiste entre o prazer e o desprazer e se repete sob forma de trauma em meio à pulsão sadomasoquista que orienta formas necropolíticas de poder em vigor desde então. Entretanto, não é suficiente apenas condenar e criticar ad nauseam essa estrutura, sem se volte a atenção também para o que está em jogo psiquicamente nas várias camadas que favorecem a manutenção de todo problema. Não será possível explorar a densidade dele aqui, mas pretendo indica-lo, ainda que brevemente.

Contra o medo da morte e da perda, que marcam uma temporalidade transitória imanente à vida, fixam-se poderes estruturalmente imutáveis, dominam-se a natureza e certas populações, formam-se jurisdições pautadas na propriedade privada e na abstração da vida efetiva, regulamenta-se política e economicamente o roubo de nossos gostos, desejos, vontades, afetos. A fixidez, o domínio, o controle e a posse do que se mostra transitório no tempo delineia justamente o gozo que orienta a violência patriarcal. Extração inesgotável de recursos naturais, exploração e opressão de povos colonizados e domínio e possessão de mulheres são imaginária e simbolicamente dispostos numa conformação cultural de modo a evitar o grande medo de certos homens brancos: a morte do que uma vez receberam ou conquistaram e a decrepitude ou a impotência de seus próprios corpos.

Se, como diz Freud, "a libido encontra nos seres vivos (multicelulares) o instinto de morte ou destruição que neles 
vigora, que busca desintegrar este ser e conduzir cada um dos organismos elementares ao estado de inorgânica estabilidade", ela também "tem a tarefa de fazer inócuo esse instinto destruidor, e a cumpre desviando-o em boa parte [...] para fora, para os objetos do mundo exterior.". É de tal desvio da pulsão de morte para o exterior que, afirma ainda Freud, observa-se "[o] instinto de apoderamento, vontade de poder". Além disso, considera que "parte da pulsão de morte desvia-se à serviço da função sexual" sob forma de sadismo, enquanto que a outra parte é retida no organismo com o acréscimo da excitação sexual, formando o prazer o masoquista erógeno. A questão é: possuir e cultivar a vontade de poder pela destruição e opressão do outro não implicam conotações valorativas alinhadas ao período histórico específico que começa sobretudo com a tecnologia moderna e os anseios imperialistas coloniais extremados até seu ápice nas guerras mundiais?

Anteriormente indicamos duas modalidades de tempo em Freud que seriam capazes de sustentar diferentes tonalidades de experiência: uma que admite a transitoriedade e o caráter contingente de qualquer acontecimento e outra que aspira a uma permanência imutável, condizente com uma universalidade que ultrapassa a efemeridade da vida humana e da natureza uma estratégia que, como vimos, é estruturalmente melancólica.

Minha hipótese é de que, embora existam autores contemporâneos a indicarem concreta e simbolicamente esse caminho efêmero como orientador de novas estruturas sociais e políticas, por uma razão específica ainda não fomos capazes de implementá-las. O que acontece em lugar disto - e lanço essa hipótese de maneira bastante insuficiente - é a perpétua reatualização de uma antiga fronteira que divide duas zonas dicotômicas nas quais estão contidas duas vertentes de temporalidade que podem reger a vida. Assim, temos de um lado o que se considera como a instável e enganadora aparência em contraste com a verdade essencialista do ser - sofistas e filósofos - ou, quase na mesma linha, de um lado o corpo mortal que definha com a passagem dos dias e se fia na sensorialidade, de outro 
a ideia imutável e universal. Também a universalidade de leis e conceitos que se contraporia à contingência da inteligência ligada à vida concreta. Ou a insistência na noção de identidade, avessa ao caráter não-identitário, estrangeiro e nômade da subjetividade que também poderiam orientar formas simbólicas e políticas. Debate que pode retroceder aos pré-socráticos com os fragmentos de Heráclito em contraposição ao eidos platônico ou, em outra vertente indicada por Barbara Cassin, a tensão entre Parmênides e Górgias.

Esses moldes fantasmagóricos orientaram uma demarcação do que era ocidental e se reatualizaram em muitos períodos da história moderna, sobretudo com o advento das políticas nacionalistas do século XIX. Entretanto, esse medo da morte e a incessante tentativa de evitá-la ou eliminá-la concreta e simbolicamente acaba por provocar o efeito inverso. Como incessante retorno do recalcado, a morte alastra-se de maneira sórdida e penetra cada um dos vários âmbitos que contornam nossas vidas no globo. Emerge sempre de novo sob forma de terror e produz incessantemente experiências traumáticas, levando à repetição de uma necropolítica para aqueles que pretendiam se livrar da morte e para os outros que sempre estiveram a ela suscetíveis. Assim, é a própria morte rechaçada que retorna como uma experiência unheimlich e impacta nossa estrutura anímica, sem perfurar mais cascas protetoras que antes pudessem impedir os choques.

Deve-se, entretanto, considerar outro medo da morte, instaurado paulatinamente pelos movimentos da dialética, identificados por Hegel: quando algum modelo concreto e simbólico busca dar lugar à transitoriedade e ao caráter efêmero de quase tudo que existe, ele automaticamente é interpretado como sendo contrário à eterna busca pela estabilidade dos bens adquiridos ou conquistados, bem como pelo anseio de uma universalidade abstrata que tudo pretende abarcar. Não demora para que formas de vida que aceitam a transitoriedade sejam atacadas por aquelas que advogavam a estabilidade inviolável de bens e posses. 


\section{Considerações finais}

Se concordarmos com Freud a respeito de que as duas espécies de pulsões operam numa "extensa mescla e amálgama, variável em suas proporções", sem que se possa considerar puramente uma e outra, as pulsões de morte e de vida operam misturadas em diferentes graus. Trata-se, por conseguinte, de dissolver sua dicotomia mecânica e fazer com que traços simbólicos lhes deem outros coloridos capazes de abarcar o eterno e o transitório que atravessam a vida na terra.

Unicórnias pretas têm asas para alçar altos voos, têm força, têm magia fantástica e graça. Têm sobretudo firmeza e valor, ingredientes capazes de sublinhar outros traços da história mnemônica e cultural. Deixemos de lados metáforas de amebas e disputas energéticas que não levam a nenhum outro lugar que não o da repetição melancólica do mesmo - nossa imaginação e poder erótico podem configurar formas mais ousadas do que a de reiterar esse velho e desbotado percurso repetitivo que se dá dentro de uma vesícula semi-morta. 


\section{Referências:}

BENJAMIN, W. (1928) Origem do drama trágico alemão. Belo Horizonte: Autêntica, 2011.

. (1940) Sobre o conceito de história. In: LÖWY, W. Walter Benjamin: aviso de incêndio. São Paulo: Boitempo, 2005.

DRIGO, L. A. "Chega de melancolia!". In: Caixa Pandemia. São Paulo: N-1 Edições, 2018.

KLEIN, M. (1957) "Inveja e Gratidão". In: Inveja e gratidão e outros trabalhos. Rio de Janeiro: Imago, 1991.

LOEWALD, H. W. Sublimation: inquiries into theoretical psychoanalysis. New Haven/London: Yale University Press, 1988.

LORDE, A. Usos do erótico: o erótico como poder. In: https://negrasoulblog.files.wordpress.com/2016/04/usos-do-erotico-o-erc3b3tico-como-poder-audre-lorde.pdf, 1984. Acesso em 02/12/2019.

The Black Unicorn. New York: W. W. Norton \& Company, 1995. Trad. em https://medium.com/@stephieborges/a-unic\%C3\%B3rnia-preta-35113dd9b6f1, Acesso em 02/12/2019.

FREUD, S. (1916) "Sobre a transitoriedade". In: Freud, S. Obras completas, v. 12. São Paulo: Companhia das Letras, 2010.

(1917) "Luto e melancolia". In: Freud, S. Obras completas, v. 12. São Paulo: Companhia das Letras, 2010.

(1920) "Além do princípio do prazer". In: Freud, S. Obras completas, v. 14. São Paulo: Companhia das Letras, 2010.

(1924) "O problema econômico do sadomasoquismo". In: FREUD, S. Obras completas, v. 16. São Paulo: Companhia das Letras, 2011.

KRISTEVA, J. Sol negro - depressão e melancolia. Rio de Janeiro: Rocco, 1998.

MBEMBE, A. "Necropolítica". In: Arte \& Ensaios, Revista do PPGAV/ UFRJ, no. 32, pp. 122-151, dez. 2016.

PARENTE, A. M. Sublimação e Unheimliche. São Paulo: Pearson, 2017.

SANTIAGO, L. “'Olhar fixo no escuro de nossa época': notas sobre melancolia, arte e parresia na contemporaneidade". In: "Correio APPOA" Número: Psicanálise à prova, Edição no. 247, agosto/2015. http://www.appoa.com.br/correio/edicao/247/olhar_fixo_no_escuro_de_nossa_epoca_notas_sobre_melancolia_arte_e_parresiàna contēmporaneīidade/ $\overline{157}$

Acesso em 01/12/2019.

"Por que ainda melancolia?...". In: Revista Miscelânia, Assis, pp. 311-333- jan.-jun. 2018. 